\title{
Sharia Board of Islamic Banks and the Attitude of Fatwa Shopping
}

\author{
Auwal Salisu ${ }^{\mathrm{I}}$,Shereeza Mohamad Saniff, Shahir Akram Hassan ${ }^{3}$
}

\author{
Centre for Islamic Development Management Studies \\ Universiti Sains Malaysia ${ }^{1,2,3}$
}

ibnsalis2002@gmail.com ${ }^{1}$, shereeza@usm.my ${ }^{2}$, shahirakram@usm.my ${ }^{3}$

\begin{abstract}
Fatwa shopping attitude is a process of searching Sharia opinions from different Sharia scholars for suitable and convenient Fatwa to suit the need of bank managers (BMs) even at the minimum level of Sharia compliance. This research was conducted to identify the Sharia Board Members (SBMs) and the new attitude of Fatwa shopping within the supervisory and advisory mandate. The objectives of this study are to identify the mandate of SBMs of IBs and to review the attitude of Fatwa shopping within the advisory and supervisory mandate. Data was collected by way of documentary review method of existing literatures, narrative analysis as well as conceptual approach of analysis. The study gathered that both SBMs and BMs have different objectives when assessing new products which create disagreement of objectives at the strategic level. The study concluded that the leniency in issuing Fatwa ruling might lead SBMs to exercise the attitude of Fatwa shopping or easily compromise toward BMs objectives. A situation of this kind has resulted many challenges toward Sharia complaint, then the products approved by SBMs which have been alleged as non-compliant to Sharia. The findings of this paper can be recommended for regulators, policy makers of Islamic banks and the body of knowledge of researchers for positive use of conceptualizing the current system to suit core component of Islamic Fatwa framework (IFF) in which the attitude of Fatwa shopping would be matter of history in near future.
\end{abstract}

Keywords: Sharia Board, Islamic Bank, Fatwa shopping and Islamic Jurisprudence. 


\section{A. INTRODUCTION}

Fatwa shopping attitude is a process of searching Sharia opinions from different Sharia scholars for suitable and convenient Fatwa to suit the need of bank managers (BMs) even at the minimum level of Sharia compliance. It is also known as forum shopping and opinion shopping by the legal professionals as well as accounting and auditing professionals respectively (Farook, S. Z., \& Farooq, 20I I)(Hosen, 2008)(Ullah, S., Harwood, I. A., and Jamali, 2018)

The Sharia governance framework of Islamic financial institution (IFIs) in Malaysia has stated the following definition and guidelines in respect of Sharia advisory council (SAC) (in charge of issuing Fatwa in Islamic Banking at national level) "The SAC of Bank Negara Malaysia is a body established under section 5I of the Central Bank of Malaysian Act 2009 that has positioned the SAC as the apex authority for the determination of Islamic law for the purposes of Islamic financial business. The mandates of the SAC among others, are to ascertain the relevant Islamic law on any financial matter and issue a ruling upon reference made to it, as well as to advise the bank and the IFIs concerned on any Sharia issues relating to Islamic financial business operations, activities and transactions" I/3 (SGFW of IFIs 20I0) P4. Furthermore, it also declared duties and responsibilities of the institutional/industrial Sharia committee as stated in the act below.

"At the industry level, the duties and responsibilities of the internal Sharia committee in advising the respective IFIs on Sharia matters were further deliberated in the guidelines on the governance of Sharia committee for the IFIs issued in 2004. The guidelines are now superseded in light of new developments in Islamic finance as well as higher expectation of the key stakeholders of the IFIs pertaining to the Sharia compliance process" I/4 (SGFW, 20I0)P4.

However, "The bank has developed the Sharia governance framework for IFIs with the primary objective of enhancing the role of the board, the Sharia committee and the management in relation to Sharia matters, including enhancing the relevant key organs having the responsibility to execute the Sharia compliance and research functions aimed at the attainment of a Sharia based operating environment" I/5 (SGFW, 20I0).

The history of Islamic banking can be traced back to half of the century during the second conference of finance ministries of the Muslim Countries held in August 1974. They agreed then to establish the Islamic Development Bank 
(IDB) which prompted the phenomenon of Islamic banking institutions to be established and appeared to become a reality (Alhajji, 2003). Furthermore, Islamic banks commenced with the instruction of handling all transactions in compliance with Sharia (Islamic Law), which stops the receipt and payment of interest, (Riba). Islamic banks circulate funds basically through investment accounts using profit and loss sharing (PLS) models, unlike conventional banks that operate based on the interest rate (Al-Deehani, T., Karim, R. A. A., and Murinde, 1999).

Meanwhile, an important aspect of the commencement of Islamic banking in Malaysia is the piecemeal approach. The setting up of Bank Islam Malaysia Berhad (BIMB) in 1983 was an important first step. Also, an important feature of the Malaysian model is that, even before the setting up of the first Islamic bank in Malaysia, there was already in place the extensive Islamic banking legislation to guide the activities of Islamic banking institutions (Alhajji, 2003). Moreover, the Islamic Banking Act was introduced in Malaysia in I983 and ensured that the operations of the Islamic banking system in Malaysia had to comply with Sharia laws. It is significant to note that, at that time, the common practice among Islamic countries over the world, whenever it was decided to set up Islamic financial institutions, a certain restrictions would merge and allocate a certain exemptions from the conventional banking regulators to degrade the effort of the people not to adopt specific Sharia regulations, and this was complemented by a set of administrative guidelines. Whereas in Malaysia, the view at that time was that, if Islamic banking was going to be established and developed into a fully-fledged system, it had to be supported by comprehensive Islamic banking legislation and Sharia regulatory framework in order to comply with Sharia laws (Ansary, Hassan \& Mutawally, 2002).

\section{Islamic Fatwa under Islamic Jurisprudence}

Fatwa refers to an act of giving answer, or a reply, or stating the decision of Islamic law upon specific issue (Mehmood, M. I., Chisti, S. A., and Mughal, 2015). It is significant to use Islamic Fatwa's component nowadays for IFIs to generate dual benefit that of worldly and hereafter in respect of the SBMs of IBs. Moreover, the concept of Fatwa is not a new topic in Islamic law. It was driven from the Qur'an in which Allah says "Before thee, also, the apostles We sent were but men, to whom We granted inspiration: If ye realize this not, ask of those who possess the Message” Sūrah Al-Anbiyāa 2I:7 (Ibn Kathīr, 2000).

The Islamic legal system fulfilled all classical and contemporary issues, since I440AH years ago, undeniably no single matter occurred without admitting 
and understanding its judgment from Sharia sources. Abu Zar Al-Gifary was reported to have said: "The Prophet thought everything before He died even the bird turns his wings in the sky" (Al-Tirmidhy, n.d.).

Furthermore, according to Al-Kathlaan (2004), most of the Muslim believers if not all of them, need contemporary transactional jurisprudence rulings in their day to day life activities. Hence, they can only reach the Islamic rules and Fatwas through Sharia academies of Fatwa at an international level notably, the Islamic Fiqh Academy of World Muslim league in the city of Mecca, kingdom of Saudi Arabia, the Islamic Fiqh Academy of Organization of Islamic Conference and Accounting and Auditing Organization of Islamic Financial Institutions; at the national level such as Sharia advisory council of Central Bank of Malaysia; and at the institutional/industrial level, for instance, Sharia board in every Islamic bank. However, it is regarded and believed that the collective Fatwa is more considered compared to the right than that of an individual (Lock, 2013).

\section{B. THEORITICAL}

(Farook, S. Z., \& Farooq, 201I)(Hosen, 2008)(Oseni, 2017) have conducted study on Fatwa shopping attitude which is the concept of searching for lenient Sharia scholars. However, this attitude may not be easy in areas with full regulatory controls but in area with weak regulatory framework where banks hire the services of Sharia consultancies rather than having their own Sharia advisors. Fatwa shopping in its literal meaning, however, might be very rarely observed in banks with their own Sharia departments and Sharia boards as disclosed by above mentioned authors. In the same vein, (Arifin, 2015) and (Zulkifli, 2006) examined and analyzed the role of Fatwa and Mufti in contemporary Muslim society using the legal thoughts of Madhhab Alshafi'T in the implementation of Islamic banking in Malaysia. Also, Mark (2007) in United Kingdom came out with the study of Islamic values as distinctive framework for moral education. He fundamentally asserts that the moral education is about inner change, which is a spiritual matter that comes through the internalization of universal Islamic values. He also referred throughout his study the existence of morality in Islam in the many verses of the Qur'an that referred in the same breath to 'those who believe' and 'those who do good deeds'. Thus, religious and moral values in Islam are granted upon every Muslims. Most importantly Islamic scholars or Muftis are the role model of the entire Ummah. So, these SBMs of IBs are in high position to acquire Islamic moral and spiritual qualities, ensuring a comprehensive Sharia compliance mechanism as well as 
observing Sharia objectives which would be established thoroughly, which would come as a result of their observation upon the awareness of Almighty Allah in all the task upon them (Mark, 2007).

Yet, the studies reviewed above did not provide valuable insights on Islamic moral and spiritual qualities according to Islamic Fatwa perspectives as one of the best aspects to encounter the attitude of Fatwa shopping, so as to avoid the prohibited transactions in IBs and as a stop-gap measure on the presence of lenient Sharia scholars and in the modern services of Fatwa shopping at the Islamic banking industry.

(Ullah, S., Harwood, I. A., and Jamali, 2018) investigates Fatwa repositioning within the hidden struggle for Sharia compliance within IFIs. The research probed the hidden battle between managers of IBs and Sharia scholars in seeking their respective objectives and at the same time, analyzed the factors creating the phenomenon of Fatwa repositioning, which was the confrontation for adjusting the level of Sharia compliance by Sharia scholars and BMs in order to meet their respective goals. The study also disclosed that SBMs and BMs have different objectives, which creates disagreement of objectives at the strategic level and presents how BMs and SBMs struggle on the ground regarding the Sharia compliance of their institutions in order to serve their different goals. Yet, the author failed to suggest Islamic moral attitudes and spiritual qualities which is the core component of Islamic Fatwa as the way out of this critical challenge affecting IFIs nowadays in general and Islamic banking industry in specific. Hence, this paper emphasize the importance on the adoption the core attitude of Islamic moral attitudes and spiritual qualities as a pre-requisite of every SBMs of IBs, then taking cognizance of such qualities would cause the attitude to improve on the spiritual awareness of the presence of Allah (Ihsan) in the heart of SBMs of IBs under the Islamic jurisprudence law, so that, the operational activities and transactions of the IBs would be made in accordance with the principles of Sharia law.

(Wardhany, N. \& Arshad, 2012) and Nidal (2009) reviewed Sharia board, the task of Fatwa, and Ijtihad in Islamic economics and finance and the unique relationship between Sharia board and IFIs. The authors explain on how the SBMs of the concerned institutions under the evaluation of the SBMs who issue Fatwa via Ijtihad which is used to derive laws from the basic principles of Sharia to address the needs of people in different places and times based on the Sharia regulations. The study again, answered the question of whether Sharia standards can be harmonized on which the matter is to be dealt with by Sharia scholars themselves and not market professionals, managers or regulators. The 
simple reason for this is because Sharia scholars are specialized in their field and whether a Fatwa can be standardized or not is a matter of religious reasoning and should be taken from Sharia own instructions and judgments and not from managers or market stakeholders. Evidently, SBMs are responsible of advising, supervising and monitoring the compliance of Sharia rules of all the transactions and issuance of Sharia products, and as a representative of the various Islamic scholars and Muftis, the SBMs has the authority to issue Fatwas regarding the products and practices employed by Islamic banks. This great and very important task must be supported by reminding SBMs with fairness of Almighty Allah and eternal reward as well as eternal punishment according to their different intentions and practices.

\section{METHODOLOGY}

\section{Islamic Qualities of SBMs in Islamic banks}

Islamic Mufti or SBMs of Islamic bank is required to obtain both moral and spiritual qualities in line with general Islamic qualities. This is in order to make Fatwa well standardized and consistent in the practices of Islamic Banking to avoid Fatwa shopping attitude and at the same time, to possess complete Sharia compliance. To achieve the above mentioned, some component of Islamic Fatwa regarding one of the most important pillars of Islamic Fatwa i.e. Islamic Mufti or SBMs must be observed and included within the terms of fit and proper criteria of Sharia governance framework of IBs and adopt it as recruitment criteria in order to face the challenges and to overcome the phenomena of Fatwa shopping attitude nowadays.

Firstly, Islamic scholars assert that it is necessary for a questioner (bank managers and directors) to seek Fatwa from people with integrity, sincerity, truthfulness and good intention (God fearing/Attaqwa/Ikhlas/Anniya Assaliha) since Alfaqih/Mujtahid/Mufti initially are supposed to be the one who really fear Almighty Allah as quoted by Imam Malik Bin Anas who was reported to have said to his students "I have never answered any Fatwa until I asked my teachers do I possess the quality of doing so? I asked Rabee'a and I asked Yahya bin Said, they all allowed me to. The narrator of the Athar asked Imam, oh Abu Abdallah, had it been they did not allow you? he said, I most stop and quit. he then said: is not good and fear for someone to declare himself for this task (Fatwa issuance) until he gets permission from his teachers" (Ibn Al- Jauzy, 2006). 
Secondly, (Imam - Alharamain, (I408, n.d.) discussed on Fatwa and Mufti in his famous Jurisprudence book and declared that it is among the conditions of a Mufti to possess attitude of Wara' in which eternal accountability and supervision (The supreme Muraqaba; observance of the presence of Allah in all his activities) will be duly regarded accordingly, in which the worldly and eternally benefits will also be considered in his activities, since a Fatwa of someone out of control of Muraqaba (Observance of Allah) may lead to the darkness of result due to the absence of complete Ikhlas (sincerity), so his view would be disregarded totally. Further clarification of Husnunniya (sincerity) and Muraqaba were made as the intention of guiding people and telling them the rules of Sharia in the sake of Allah without Riyaa (feeling above all else) as well as eternal accountability and supervision. These would help Islamic Mufti in delivering Fatwa in a successful manner, since actions are judged according to intentions.

In order to overcome the attitude of Fatwa shopping among SBMs of Islamic banks, and to maintain complete Sharia compliance, the following structure in the figure below should be observed and adopted in governance framework of IBs.

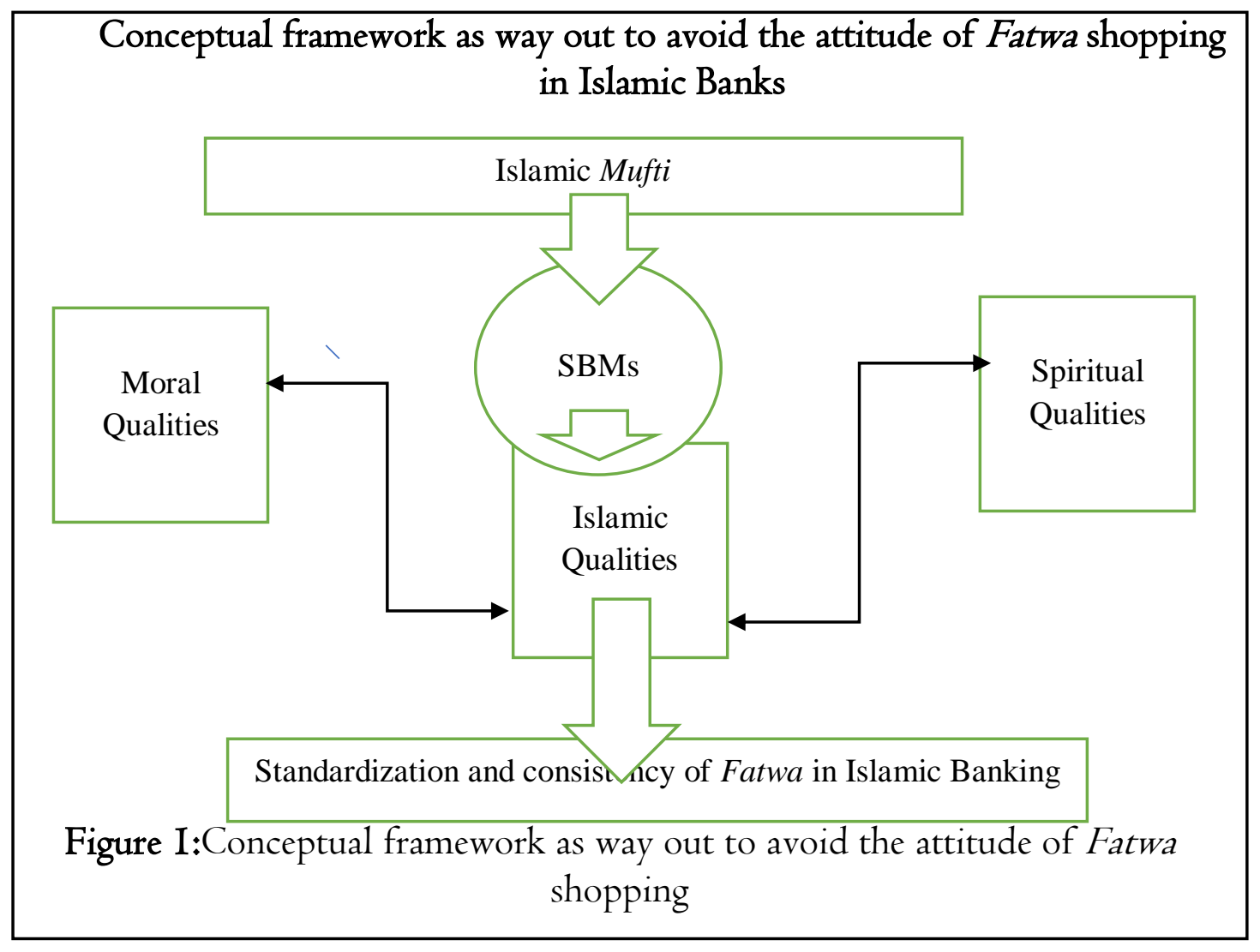


The above figure is the main content of Islamic Fatwa which is proposed to be considered in governance framework of Islamic banks

\section{RESULTS AND DISCUSSION}

SBMs are the backbone of every IBs. They are the Muftis of such banks. As such, acquiring Islamic qualities generally would be a great opportunity upon them to exercise their mandate with Islamic moral and spiritual qualities which includes but not limited to a Sharia qualified Muslim scholar: legally responsible (Mukallaff), reliable, trustworthy, humble, kind and gentle, God fearing, sincere (good intention), before the issuance of Fatwa. Based on the review of literatures and past researches this paper has put forth a preliminary suggestion that possessing Islamic manners and spiritual qualities of SBMs would be the best standard of not compromising in the interest of BMs. The above-mentioned qualities should be part of the criteria in respect of SBMs of IBs in its Sharia governance framework. This is in order to comply with general Islamic ethics when assessing new products and to avoid disagreement of objectives at the strategic level so that there would not arise situation of Fatwa shopping among the SBMs (Alhajji, 2003).

The following are some of the verses and traditions in which Islamic moral and spiritual qualities are mentioned thoroughly. It it is also suggested by well experienced SBMs of IBs to be adopted and considered upon SBMs of Islamic banks:-

I-Integrity, Sincerity, Truthfulness and Good intention (God fearing/ Attaqwa/Ikhlas/Anniya Assaliha), as an SBM one needs to clean his intention for the mandate to be performed in the sake of Allah as declared by

Surah Al-Bayyinah 98: 5. "And they have been commanded no more than this: To worship Allah, offering Him sincere devotion, being true (in faith); to establish regular prayer; and to practise regular charity; and that is the Religion Right and Straight".

Also mentioned in Surah At-Talaaq, 65: 2 - 4. "And for those who fear Allah, He (ever) prepares a way out" "And He provides for him from (sources) he never could imagine. And if anyone puts his trust in Allah, sufficient is ((Allah)) for him. For Allah will surely accomplish his purpose: 
verily, for all things has Allah appointed a due proportion" and for those "who fear Allah, He will make their path easy".

This would initially link to the successful supervision of IBs as promised by Almighty Allah. Again, Umar Bin Khattab was reported to have said,

"I heard Allah's Apostle saying, "The reward of deeds depends upon the intentions and every person will get the reward according to what he has intended. So, whoever emigrated for worldly benefits or for a woman to marty, his emigration was for what he emigrated for" (Al-Bukhary, (304 A.H.). Bukhary, Muhammad Bin Ismail Albukhary, 2009)(Lock, 2013).

2-Eternal accountability and supervision (The Supreme Muraqaba) in which the observance of the Almighty Allah in secret as well as in the public (Muraqaba) (Observance of Allah) will be duly observed so as to benefit in worldly and eternally reward. This quality is upon everyone as confirmed by Quran in

Surah A1-Ista', I7: 36, "And pursue not that of which thou hast no knowledge; for every act of hearing, or of seeing or of (feeling in) the heart will be enquired into (on the Day of Reckoning".

Surah Qaff, 50:I8 "Not a word does he utter but there is a sentinel by him, ready (to note it)".

Surah Al-Infitar, 82: 10 - 13. "But verily over you (are appointed angels) to protect you,- "Kind and honourable,- Writing down (your deeds): "They know (and understand) all that ye do".

And the last but certainly not the least, SBMs should always remember that they are the backbone of the IBs. If they succeed in the act of advisory and supervisory then the whole financial interaction will do the same and vis-a-vis with this, they comply with

Surah Al-Hujuraat, 49: I0 "The Believers are but a single Brotherhood: So make peace and reconciliation between your two (contending) brothers; and fear Allah, that ye may receive Mercy"

and 
Sharia Board of Islamic Banks and the Attitude of Fatwa Shopping

Auwal Salisu ${ }^{1}$, Shereeza Mohamad Saniff², Shahir Akram Hassan ${ }^{3}$

Surah Al-Ma aidah, 5:2 "Help ye one another in righteousness and piety but help ye not one another in sin and rancour: fear Allah. for Allah is strict in punishment"

as they bring Muslims nearer to Almighty Allah with the successful business transaction and interaction accordingly.

\section{E. CONCLUSION}

To this end, the influence of bank managers toward SBMs that leads to the phenomena of Fatwa shopping when assessing new products and avoiding disagreement of objectives at the strategic level can be easily overcome with conceptualization of core components of Islamic Fatwa under Islamic jurisprudence as shown earlier in the conceptual framework. With this in place, the attitude of Fatwa shopping would be a matter of history in near future.

The study recommends that other IFIs should maintain this standard and to include within its criteria of Sharia governance framework of IBs and to adopt it in order to face the challenges and to overcome the phenomena of Fatwa shopping that is experienced today. 


\section{REFERENCES}

Al-Bukhary, (304 A.H.). Bukhary, Muhammad Bin Ismail Albukhary, S. A. (2009). Translator: M. Muhsin Khan, Volume I - 7 / I700, Retrieved on Ist October 20I9, from https://dI.islamhouse.com/data/en/ih_books/ single/en_Sahih_Al-Bukhari.pdf.

Al-Deehani, T., Karim, R. A. A., and Murinde, V. (1999). The capital structure of Islamic Banks under the contractual obligation of profit sharing. International Journal of Theoretical and Applied Finance, 2(03), 243-283.

Al-Tirmidhy, (352 A.H). (n.d.). Muhmmad Isah saura Musa Addahhak SunanAttirmidhy, Sharikat MusdfhaAlbabyAlhalaby, Egypt.

Alhajji, H. M. (2003). Islamic Economics a nonpublished Arabic book of Islamic Economy. Jordan.

Arifin, H. M. (2015). The Influence of Competence, Motivation, and Organisational Culture to High School Teacher Job Satisfaction and Performance. International Education Studies, 8(I), 38-45.

Farook, S. Z., \& Farooq, M. O. (20 I I). Incentive- based regulation for Islamic banks. Journal of Islamic Accounting and Business Research.

Hosen, N. (2008). Online Fatwa in Indonesia: From Fatwa shopping to googling a Kiai.

Ibn Al- Jauzy, A. A. bin M. bin A. (2006). Ta'zimulFityah, Addarilathariyya, 2nd edition.

Ibn Kathi $\square$ r, I. (2000). Tafsir ibn kathir: (abridged) (Ist ed., Misb $\square$ a $\square$ h $\square$ almuni $\square$ r fi $\square$ tahdhi $\square$ b). Riyadh: Darussalam.

Imam - Alharamain, (I408, A. H. (n.d.). Abdulmalik bin Abdullah bin Yusuf Muhammad aljuwainyabulmaaly, ruknuddeAl'ijtihad, Dar aluloomwathaqafa, Damascus, Beirut.

Lock, M. (2013). The Adab Al-Mufti being a translation from the introduction to Al-Nawawi'Majmu'. Islamic Sciences, II(2), II3.

Mehmood, M. I., Chisti, S. A., and Mughal, M. J. (20I5). Islamic concept of Fatwa, Practice of Fatwa in Malaysia and Pakistan: The Relevance of Malaysian Fatwa model for legal system of Pakistan. International Research Journal of Social Sciences, 48.

Oseni, U. A. (2017). Fatwā shopping and trust: towards effective consumer protection regulations in Islamic finance. Society and Business Review.

SGFW. (20I0). Sharia Governance Framework SGF 2010 Retrieved on Ist October 2019.http://www.bnm.gov.my/guidelines/05_Sharia/02_Sharia_Governa 
Sharia Board of Islamic Banks and the Attitude of Fatwa Shopping

Auwal Salisu ${ }^{\mathrm{I}}$, Shereeza Mohamad Saniff ${ }^{2}$, Shahir Akram Hassan ${ }^{3}$

nce_Framework.

Ullah, S., Harwood, I. A., and Jamali, D. (2018). Fatwa repositioning the hidden struggle for Sharia compliance within Islamic financial institutions. Journal of Business Ethics, I49(4), 895-9I7.

Wardhany, N. \& Arshad, S. (2012). The Role of Sharia Board in Islamic.

Zulkifli, H. (2006). Roles of the Islamic Financial Institution in combating money laundering: Legal and Sharia perspectives. Malaysia: Islamic Business Researches Centre. 